\title{
Chapter 5 \\ Patriots in France, Political Talks Between 1500s and 1650s
}

At the start of the sixteenth century, the French were faithful adherents of the Roman Catholic Church. Throughout Europe, the clergy's abuse of privileges and power led to discontent, expressed by people who would become known as 'Protestants'. The Catholic Church failed to address these feelings of dissatisfaction and considered them to be heretical thoughts. Such dismissal led to the birth of the so-called Protestant Church. The adherents belonging to this church were by no means a homogenous group: Martin Luther, Huldrych Zwingli, and John Calvin were the most known influencers. Combined with humanistic and renaissance approaches of life, these men of the Reformation appealed to many people. The Catholic Church felt threatened by the rise of these-in their eyes-heretic groups, and saw the French king as a powerful ally.

The French crown promoted Catholicism as the only true religion and had Protestants prosecuted. Many chose to flee, but this was only possible if one's finances permitted it. Others became façade-Catholics, pretending to be something they were not. ${ }^{1}$ Many scholars have argued that this internal disorder became the primary cause of a series of interrelated wars in France between 1562 and 1598. Nevertheless, Philip Benedict and others have emphasised that political issues raised during the period aggravated this internal disorder. ${ }^{2}$ He quotes a contemporary Catholic historian François de Belleforest, who stated that the rivalry between, and ambitions of, the nobility were a cause of much strife and hatred. A contemporary protestant historian Lancelot Voisin de La Popelinière stated more or less the same: passions caused troubles and were veiled under the pretence of fighting another religion. ${ }^{3}$ The Catholic League (1585) was diffuse in its ambitions: on the one hand,

\footnotetext{
${ }^{1}$ van der Linden (2016).

${ }^{2}$ Benedict (2016).

${ }^{3}$ Ibid., pp. 60, 63-64.

(C) The Author(s) 2021

C. A. Romein, Protecting the Fatherland: Lawsuits and Political Debates in Jülich, 
it aimed to safeguard the French throne from a Protestant king, but on the other hand, it also sought to object to tax raises and royal favouritism. ${ }^{4}$

In this second part, we shift our focus to the Kingdom of France, or more particularly, to the province of Brittany. I provide an overview of the main political events from the mid-sixteenth until the mid-seventeenth century, as well as the developments in political thought. I do this in broad strokes, as a general background in which to situate the developments of the absence of the use of fatherland terminology in Brittany (see: Chap. 6)..$^{5}$

\subsection{Political Developments: Kings, Children, and Succession}

The French throne had been particularly weak since the mid-sixteenth century. Henry II was the last person to become king as an adult; all the kings who died after 1547 had left the throne to an infant. ${ }^{6}$ During such extended periods of regency, rivalry amongst the nobility increased, as its members sought to gain access to the court and convince the young king and his regent to pursue a policy of their liking. If infant kings and their regents were already a hazard, this was indisputably the case for murdered kings or the extinction of a bloodline. Jacques Clément mortally wounded King Henry III (1551-1589), and the king died one day later, on 2 August $1589 .{ }^{7}$ His brother, the Duke of Alençon, had already died in 1584 , which meant that the Valois-dynasty was extinct. ${ }^{8}$ According to Salic Law, the French throne had to go to the closest related male heir of the late king, which in this particular case meant that a successor was found in the twenty-second degree. ${ }^{9}$ Predictably, many questioned the legitimacy of this inheritor, not in the least because the successor was Henry IV, King of Navarre who had been raised a Protestant by his Calvinist mother. ${ }^{10}$ In order to inherit the French Catholic throne, the Catholic baptised Henry VI had to re-convert to Catholicism. ${ }^{11}$

During his reign, Henry IV presented himself as a modern king, who sought to leave feudalism in the past. Hence, his rule is often seen as the start of arbitrary rule,

\footnotetext{
${ }^{4}$ Ibid., p. 66.

${ }^{5}$ Many, in-depth studies into the political history and the history of political thought in France have been written. This chapter is certainly not meant to repeat this works, but merely sketches developments. For more information, see for example: Bély (2009); Collins (2021) I would like to thank professor Collins for allowing me to read parts of his book before publication.

${ }^{6}$ Collins (2017), p. 102.

${ }^{7}$ Greengrass (2004), p. 176.

${ }^{8}$ Bonney (1991), p. 23.

${ }^{9}$ Mousnier and Spencer (1973), p. 106.

${ }^{10}$ Bonney (1989a).

${ }^{11}$ Bonney (1991), p. 30.
} 
since Henry IV made decisions by merely stating that it pleased him to do so. 'Puissance absolue' meant that the king was not subjected to any other worldly power - not to the emperor, nor the Pope. ${ }^{12}$ As a result, Henry IV did not shy away from alliances with, and support for, Protestants. For example, during the early stages of the succession crisis in Jülich-Berg-Cleves-Mark he supported the Dutch and sided with the Protestants. Henry's choices in foreign politics led to the belief among the people that he had not renounced his Protestant upbringing. The issue of religion, combined with the low degree of relative consanguinity, nursed the idea that King Henry IV had usurped the throne as a tyrannus absque titulo (tyrant without a title). ${ }^{13}$ All of these issues seem to have contributed to the king's murder on 14 May 1610. His assassin François Ravaillac claimed to be a good Catholic, who had acted upon his true Christian beliefs by committing regicide to remove a tyrant. ${ }^{14}$ Roland Mousnier claims that it was the limited toleration of the Huguenots in the Edict of Nantes (1598) that led Ravaillac to the belief that the king had failed to convert the Protestants, and had thus forsaken his duties as king (Map 5.1) ${ }^{15}$

Subsequently, King Louis XIII ascended the throne, under the regency of his mother Maria de' Medici. Her regency, however, did not last long. The Italian-born Queen-mother was suspected of favouring the Italians-especially minister Concino Concini-who worked in France's service. In 1617, the regency ended, and Concini was killed after allegedly resisting arrest. ${ }^{16}$ Maria de' Medici was sent into exile to the Château de Blois. Only seventeen years of age, King Louis XIII accepted government over France and began to govern in his own right, with the help of his trusted friend Charles d'Albert, Duke de Luynes. Unfortunately for the young king, De Luynes passed away only a few years later, in $1621 .{ }^{17}$ Shortly after the duke's death, Cardinal de Richelieu came to the fore. He re-established the relationship between King Louis XIII and his mother, which led to Cardinal de Richelieu's rise to a place in the royal council.

King Louis XIII entrusted Cardinal de Richelieu with the financial affairs of France, as he had little knowledge of the matter. In 1624, Cardinal de Richelieu became the first minister and could do as he pleased. ${ }^{18}$ Although he maintained the status quo, he encountered some resistance from the Grandees (highest nobles), mainly from Gaston d'Orleans. Reforming the country turned out to be incredibly difficult. In legal matters, for example, Richelieu was met with significant resistance on the part of the aristocracy when he banned duelling. ${ }^{19}$ In foreign affairs, Richelieu tried to find allies against the Habsburg dynasty. In France, he tried to gain the

\footnotetext{
${ }^{12}$ Collins (2021).

${ }^{13}$ Bulst (2004), p. 124.

${ }^{14}$ Bonney (1991), p. 27.

${ }^{15}$ Ibid., p. 37; Mousnier and Spencer (1973), p. 22.

${ }^{16}$ Bonney (1981), p. 819.

${ }^{17}$ Chisholm (1911) Luynes. Encyclopædia Britannica 147.

${ }^{18}$ Bonney (1992).

${ }^{19}$ Bély (2009), pp. 206-208.
} 


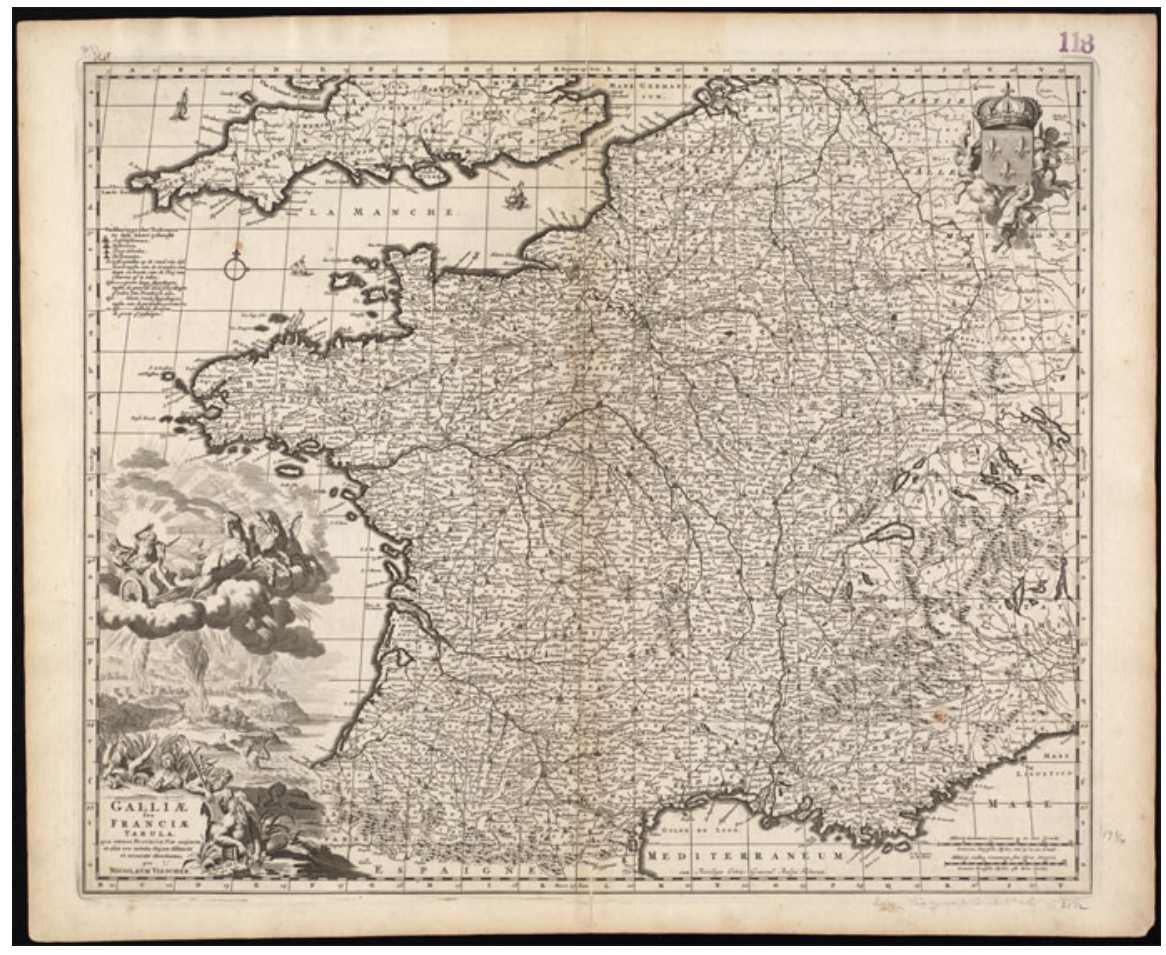

Map 5.1 France (seventeenth century). Map by Nicolaes Visscher, Galliae seu Franciae tabula, qua omnes provinciae, viae angiariae, et aliae res notatu dignae distincte et accurate ostendatur (1690). Scale: [ca. 1:2,500,000]. Map reproduction courtesy of the Norman B. Leventhal Map \& Education Center at the Boston Public Library. https://collections.leventhalmap.org/search/ commonwealth:cj82kq901. Accessed November 23, 2020

Protestants' support by arranging the marriage of Princess Henrietta Maria to the Protestant King of England: a downright provocation to the Pope despite the princes remaining a Catholic. In 1625, France began to move its armies against Spain in Northern Italy, which aggravated the Spaniards enormously. In order to rally support for his foreign policy, Cardinal de Richelieu started to influence public opinion using pamphlets. Having secured political ties with England, the cardinal now turned his gaze to the revolting Protestants in the stronghold of La Rochelle. After reconquering it, he shifted his attention to the Habsburg possessions in Northern Italy once again. France and Sweden got along quite well too, supporting the antiHabsburg forces financially and militarily.

By 1630, the health of the king declined, and fears arose that he would soon die. At this point, the Queen-mother demanded Cardinal de Richelieu's leave. However, King Louis XIII, who was satisfied with his minister's services, refused her demand. Richelieu's policies were either applauded by those who sought war against Spain; or despised by those who held the Spanish in high regard. In 1635, France became involved in the Thirty Years' War, indirectly supporting the Hessian and Swedish 
troops. Additionally, France started pursuing the conquest of the principalities to the west of the Loire-river-Alsace - and in the North. In 1635, the Franco-Spanish War erupted, and France found itself surrounded by the Habsburg dynasty and its supporters. $^{20}$ The Spanish Prime Minister Gaspar de Guzmán, Count-Duke of Olivares, hoped to be able to attack France from all sides at once, but this plan failed. The French found themselves in peril when towns only 120 kilometres away from Paris collapsed in the face of enemy troops; people began to panic and revolt. Step by step, the French regained terrain. From 1636 onwards, the Spanish and French monarchies both suffered from revolts. In both kingdoms the people turned against their monarchs as a result of the expenses of warfare. Both parties calculated that perseverance would increase the chances of a victory because internal conflicts would wear their enemy out. This situation continued until well after Cardinal de Richelieu's death on 4 December $1642 .^{21}$

On the day of King Lous XIII's death (14 May 1643), it was decided that Queen Anne and a council were to act on behalf of the minor King Louis XIV. During the early years of his reign, personal ties to the king himself were virtually absent, and people depended on their connections to those in the vicinity of the crown-Queen Anne, Cardinal Mazarin and some extent the Princes-du-Sang (royal princes, closely related to the crown). Contemporaries considered the period of political instability in France (1648-1653), commonly known as the Fronde, to be a civil war. The nobles could not solve the problems, as they had their organisational issues and lacked a common objective. ${ }^{22}$ The financial situation of the nobility, and hence their political interests, varied considerably. High-ranking nobles with many resources were close to the crown - as they functioned as moneylenders-and had strong patron-client relations. Collins claims that the causes of the Fronde should be sought in the financial troubles and pressure in the provinces to help out the crown financially, and subsequently, in a problematic situation in Paris. Disgruntlement with policy spread from the peripheries to the capital. He even writes that: '[t]he Fronde did not lead to the breakdown of order; rather, the breakdown of order led to the Fronde. ${ }^{23}$ Only through the use of established patron-client-relationships, thus ensuring their loyalty, was greater evil averted in $1648 .^{24}$ The consequences of the foreign policywar in the Holy Roman Empire and against Spain-influenced the economy in various ways, and gave rise to the Fronde. War had taken its financial toll, in the sense of increased taxation, the creation of offices and increasing debts. ${ }^{25}$

Between 1646 and 1648, it seemed as if Cardinal Mazarin had deliberately tried to prolong the war to ensure financial gain and to strengthen his position. ${ }^{26}$ When the

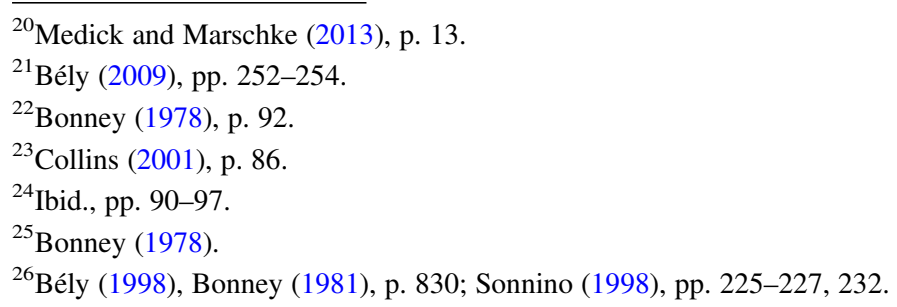


government did not attempt to end the war, people started to feel anxious. The parlement endorsed these feelings and objected against new taxes, which were considered too heavy a burden for the people. ${ }^{27}$ This first phase of critique and uprising started in the spring of 1648. It became known as the 'Fronde of the Parlement' or Fronde of the 'judges'. Cardinal Mazarin's government allegedly made two critical errors in this first phase. Firstly, he asked for more resources while leaving the grievances of officers unaddressed. Secondly, he allowed the Chamber Saint-Louis, a meeting of thirty-two delegates from the various Parisian bureaucratic courts, to assemble and make agreements meant to solve officers' problems. The instability of the times, however, brought these decisions into question. ${ }^{28}$ The costs of Cardinal Mazarin's government exploded, and a desperate search for finances started; simultaneously, the Chamber Saint-Louis was in search of a way to lighten the people's burden. According to some texts, Cardinal Mazarin's corruption was at odds with peace, and, therefore, troublesome. The Fronde was more a rebellion in the interests of the people than a reform movement. ${ }^{29}$

In the five years of the Fronde, about 5400 pamphlets were written, reflecting the public opinion via a plethora of anonymous voices. ${ }^{30}$ These texts are known as Mazarinades. ${ }^{31}$ During the first year, there were only a few hundred, in the following years, however, the number of pamphlets rose to well over a thousand a year. They were well-written, probably by professional, learned authors, and addressed the public problems created by Cardinal Mazarin's government. ${ }^{32}$ Not all texts opposed arbitrary rule, as some did agree with the idea of a strong and centralised state. The complainants' primary cause of grievance seems to have been the fact that they just did not like the Italian cardinal. These pamphlets became a salient way to describe current affairs, and showed a keen eye for recent developments.

The second phase of the Fronde started with the arrest of three high noblemen: the princes-du-sang de Condé and de Conti, and their brother-in-law the Duke de Longueville. Their arrest happened unexpectedly on 18 January 1650 - at the behest of Mazarin himself-and they were imprisoned in the Vincennes-castle. One of the factors that had contributed to this event was the feud between the prince-du-sang Condé and Cardinal Mazarin; another was the cardinal's already unstable position. ${ }^{33}$ Several authors of pamphlets demanded Mazarin's resignation, replacing him with the Prince de Condé, the Duke de Retz or any other high official. ${ }^{34}$ These requests show the true nature of the Fronde: it was a battle over which individual or group

\footnotetext{
${ }^{27}$ Bély (2009), p. 305.

${ }^{28}$ Bonney (1984).

${ }^{29}$ Ibid.

${ }^{30}$ Jouhaud (1983), Bonney (1989b).

${ }^{31}$ Collins (2001), p. 96; Jouhaud (1985).

${ }^{32}$ Most authors seem to have read Machiavelli, according to: Carrier (1969), Collins (2001), p. 96; Jouhaud (1985).

${ }^{33}$ Bonney (1981), p. 92.

${ }^{34}$ Collins (2001), p. 95.
} 
should have control over the government of France. ${ }^{35}$ In these pamphlets, the focus was on the interest of France rather than on the virtues of the people. Those in power were looking for ways to expand their influence at the cost of their opponents. ${ }^{36}$ Luckily for Cardinal Mazarin, each step he took was supported by the Queen-regent, Anne of Austria. However, despite the Queen's support, Mazarin eventually was forced to flee, since there was little support for his actions or the increased level of taxation. The heavy-burdened population revolted against their Italian minister, whom they believed to be the cause of all their problems. The cardinal left but swiftly returned, with approximately 6000 mercenaries, just as France opened peacenegotiations with Spain. The situation with the French Princes-du-Sang also remained troublesome, as they required an infusion of Spanish money to fund their troops while negotiating peace. Cardinal Mazarin, on the other hand, was able to finance his troops by drawing on his vast financial resources to finance his troop. $^{37}$

\subsection{Governmental Organisation: Tasks, Taxes, and Ties}

In the early $1500 \mathrm{~s}$, French society, was unequal, both in terms of status and in terms of income. As a result of the medieval feudal system, the government was divided into many hands. ${ }^{38}$ The nobility held many privileges over their tenants and the inhabitants of their dominion, allowing them to cast judgments, rule their property, and collect taxes. Nevertheless, they were still bound to the French king, as he was the one who allowed them to govern their land in exchange for advice and military aid (consilium et auxilium). The God-given sovereign power of the French king was - in the words of Bodin: inalienable, indivisible, and perpetual. ${ }^{39}$ His tasks shifted gradually, firstly from finding legislation to making laws, by kings such as Francis I. Subsequently, his seventeenth century-successors started to administer the legislation. ${ }^{40}$ The king was assisted by a small group of people, each with his own expertise, who took part in a large council. ${ }^{41}$ This council was divided into four different specialised councils, each with its task: ${ }^{42}$ Conseil d' état/ conseil des

\footnotetext{
${ }^{35}$ Ibid., p. 95.

${ }^{36}$ Ibid., p. 96.

${ }^{37}$ Bonney (1989b).

${ }^{38}$ Collins (2001), pp. 8-9.

${ }^{39}$ Ibid., p. 16.

${ }^{40}$ Ibid., p. 6.

${ }^{41}$ Ibid., pp. xxi-xxii, 16.

${ }^{42}$ Based on: Moote (1971), p. 3.
} 
affairs, ${ }^{43}$ Conseil d' état et des finances, ${ }^{44}$ Conseil des finances, ${ }^{45}$ and the Conseil des parties. ${ }^{46}$ The protection of the people became more and more a task of the royal government and these councils, especially after the 1628-recapture of La Rochelle. ${ }^{47}$ With officials holding positions as minister (this French word means literally 'servant'), counsellor or secretary, the system developed towards one in which every area of France was assigned to a specific minister. There were many officeholders involved in ruling France all of whom were stationed in Paris. These officeholders seemed to slowly replace the old feudal structure, slowly breaking the position of the Grandees down. ${ }^{48}$

King Henry IV had the habit of signing documents with the phrase 'for such is our pleasure. ${ }^{49}$ This phrase has often been interpreted as a sign of arbitrary rule. However, too much has been made of this phrase, as it only meant that the king had the undivided right to make laws, but was still accountable to God, and bound by God's laws. If this were not the case, he would become a tyrant. ${ }^{50}$ In short, the administration of France focussed on three things: it administered justice and made policy, it fought wars, and it levied taxes to pay for these wars. ${ }^{51}$ France largely depended on officeholders who had bought offices in their lifetime; however, whether the office was bought or not depended to a great extent on the crown's need for money. Being a judge was considered a part of the standard noble prerogative, and those non-nobles who bought the office became, therefore, known as noblesse de robe, in contrast with the noblesse d'épée. The creation of offices was one way in which wealthy merchants could become part of the nobility and move up the social ladder. ${ }^{52}$

Levying taxes and applying and administering justice in civil cases remained difficult, since much depended on local customary law and cooperation of local assemblies of the états, for example in the Pays d'État. Depending on the history of a region, there could be room to negotiate the amount of taxes to be paid. There were three different types of regions: pays d' élection, pays d' états and pays d'imposition. The latter were regions that were the result of recent conquests. Here, an appointed royal intendant would oversee the levying of taxes, while much of these areas' original tax-system remained intact. Most of France fell into the category of pay $d^{\prime}$ élection. Here as well, an appointed intendant (intermediate) oversaw the imposition of taxes. It was not possible to buy this office since this might lead to corruption. The

\footnotetext{
${ }^{43}$ Council for general policy-making.

${ }^{44}$ Council for financial affairs.

${ }^{45}$ Council for acquirement and distribution of revenues.

${ }^{46}$ Council for the supervision of justice.

${ }^{47}$ Collins (2001), p. 9.

${ }^{48}$ Moote (1971), p. 35.

${ }^{49}$ Collins (2001), pp. 2-3.

${ }^{50}$ Bély (2009), p. 36; Collins (2001), pp. xx-xxi.

${ }^{51}$ Collins (2001), p. 10.

${ }^{52}$ Ibid., p. 22; Collins (2003), p. xiv.
} 
impôts (taxes) were collected with the aid of the élus (Eng. elected). The pays $d^{\prime}$ élection had little autonomy, and since the Estates-General did not assemble, there was hardly any room to negotiate about taxes. ${ }^{53}$ During the seventeenth century, there was a change in the people who were held responsible for the taxes. Taxes had to be collected by a local parish, who had an obligation to collect the whole sum. However, if not all the money was collected, the parish was bound by the principle of common constraint. The parish itself had to pay the missing part. ${ }^{54}$ Another system of tax collecting was applied to direct taxes, where tax-farmers would pay the crown a fixed sum of money, and consequently could do as they pleased. ${ }^{55}$

The number of pays d' état steadily diminished in the seventeenth century. The most well-known were Béarn, Dauphiné, Guyenne, Languedoc, Burgundy, Provence, and Brittany. After 1650, only the last three still held this position. Here, requests for taxes went through the états, who could negotiate- to some extentand decide the distribution of taxes. Low direct taxes were beneficial to the nobility, as their tenants would still be able to contribute to the nobles' maintenance as part of their duty. ${ }^{56}$ Patrons who had access to the crown could negotiate the terms of their taxes. No intendant would oversee the taxes since this was a provincial matter. ${ }^{57}$

Together with the aforementioned specialised councils, the king ruled his country. The prime minister, that is Cardinal de Richelieu, and later Cardinal Mazarin, could make proposals, which the king would then approve. The king also had governors, mostly relatives or clients, who did his bidding in the provinces. $\mathrm{He}$ was continuously short on money and needed to find ways to finance his expenses. Selling offices provided an income, but loans were still necessary. Hence, financiers became incredibly crucial to the system, not in the least because they also bought equipment for the army. The conventional system of justice monitored the financers, but the king decided on protection against prosecution for his much-needed moneylenders. ${ }^{58}$

The most notorious taxes in France were the taille and the gabelle. The taille was a land tax introduced during the Middle Ages in order to obtain more money quickly and eventually became a standard royal tax. People despised it, (just as they despised the gabelle (salt-tax)) since it directly influenced the income of the inhabitants. Although the gabelle was an indirect tax, salt was a much-used product, and hence the tax had a substantial impact as well. During the late sixteenth and the seventeenth century, tax-farmers collected most taxes. Initially, the king had an obligation to assemble the Estates-General, but this did not continue after 1614. Tax-farmers paid the king the requested amount upfront, in exchange for the right to collect money in a

\footnotetext{
${ }^{53}$ Bély (2009), pp. 54-63.

${ }^{54}$ Collins (2001), p. 26.

${ }^{55}$ Ibid., p. 26; Bonney (1979).

${ }^{56}$ Collins (2001), p. 24.

${ }^{57}$ Bély (2009), pp. 54-63.

${ }^{58}$ Ibid., pp. $54-63$.
} 
specific geographical area. It should not come as a surprise that this office was often accused of extortion.

With the influence of the feudal system diminishing, a new system of importance arose: the patron-client relationship. ${ }^{59}$ Patronage is to be understood as a situation in which a person actively builds a social network of people (clientele)—often of lesser status - with a particular political intention, aiming to influence or control a society's decision-making. Under this system, clients earned protection and favouritism in return for their loyalty and service to the patron. ${ }^{60}$ Most of this happened informally. For example, the nobility could be asked to be the godfather of a farmers' child, but peers could also request such favour. Divisions were not necessarily made among noble and non-noble lines; money, personality, private interest, personal affection, and loyalty were of more importance. ${ }^{61}$ Self-interest dominated the patron-client relationship, and could thus shape political actions. ${ }^{62}$ This self-interest also explains the ease with which alliances changed and loyalties shifted.

\subsection{Political Thought: Sovereignty, Reason, and Patrie}

During the Middle Ages, the duties and obligations of princes within their jurisdiction were ill-defined, and can be characterised as a process of 'testing the limits. ${ }^{63}$ During the fifteenth and sixteenth century, governments steadily obtained more power, due to the increasing efficacy of the means used to govern a growing number of people. There was increasingly more contact with other parts of the world. This was partly caused by trade, but also by monetarisation as a result of the development of banks. Furthermore, the success of the printing press made it possible for a prince-and others - to disseminate texts, in order to inform people on decisions that were made and implemented. ${ }^{64}$ At the same time, dynastic ambitions gave rise to more wars. As a result, princes sought ways of finding the means to pay their armies through increased taxations, using tax-farming, or by borrowing money from wealthy merchants. ${ }^{65}$

Throughout Europe, princes and their Landstände or états-or whatever name they held-explored the limits of their powers. In France, Jean Bodin's Les six Libres de la République (1576) settled the matter. Breaking with the medieval

\footnotetext{
${ }^{59}$ Kettering (1986), p. 409.

${ }^{60}$ Ibid., p. 410.

${ }^{61}$ Schalk (1986).

${ }^{62}$ Kettering (1986), p. 411.

${ }^{63}$ Kossmann (2000), pts 2. Popular Sovereignty at the Beginning of the Dutch Ancien Regime, 133.

${ }^{64}$ Ibid., p. 134.

${ }^{65}$ von Friedeburg RCF (2010) State Forms and State Systems in Modern Europe. In: European History Online (EGO) published by the Institute of European History (IEG), Mainz. http://www. ieg-ego.eu/friedeburgr2010-en. Accessed 30 January 2019.
} 
interpretation of rights and obligations, Bodin reasoned that: '[...] firstly, that the sovereign wielded all political power, and secondly that this power derived from the right to legislate. ${ }^{66}$ In other words, all power was ascribed to the King of France, with some possible exceptions. With this innovative approach, Bodin managed to address two issues. Firstly, the disagreements over what the king could and could not do. Secondly, he addressed the king's increased sphere of influence. Instead of an ever-growing list of attributed powers, Bodin worked with a positive list. ${ }^{67}$ Addressing sovereignty did make Bodin sound something like an adherent of arbitrary monarchy, which he denied since he stated that a prince should not overstep the boundaries of ' $[. .$.$] divine, natural or fundamental laws nor, for example, levy$ taxes arbitrarily. ${ }^{68}$ Bodin's positive list broke with medieval traditions and interpretations of attributed power, and centralised all power in the monarch. Bodin himself defined it as follows: La souveraineté est la puissance absolue \& perpetuelle d'une République, que les Latins appellent majestatem'. 99 The book, written in French, gained much attention, as it was immediately accessible to a broad audience.

With that, Bodin's book outpaced the ideas of the 'reason of state', which, with the exception of Machiavelli's Il Principe, were not yet written down, and therefore circulated only among the high nobility. Referring to the amoral prince of Machiavelli was often not done; however, it did influence thinking about the role of princes and the 'state'. Giovanni Botero's (c. 1544-1617) interpretation of 'reason of state' was published in 1589 in his Della Ragion di Stato. Botero understood it as a means of preserving the kingdom or principality (the 'state'). ${ }^{70}$ As Maurizio Viroli explains, the prince and his principality still formed a closely intertwined unity: the 'reason of state' and the 'state of the prince' were the same thing. According to Viroli, this becomes clear when Botero initially fails to address the issues of sovereignty or give a definition of a 'state' but then does define the latter as '[...] a firm rule over a people (un dominio fermo sopra popoli) ${ }^{71}$ Botero rejected the search for 'great things', which, according to Machiavelli, would have been the greatest achievement of a prince to pursue. ${ }^{72}$ According to Botero, a prince should possess four classical virtues:

[...]if he wants to maintain his dominion over a people, a prince needs to rely on justice and liberality, which help him keep the love of his subjects, and prudence and valour, which are the conditions of a good reputation. ${ }^{73}$

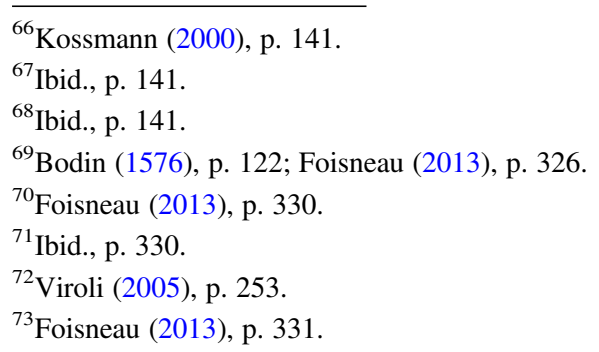


Here, Botero differs from Bodin's definition of good government, as he ascribes five characteristics to the-impersonal-term, sovereignty. Firstly, the king had the power to create legislation applicable to everyone. ${ }^{74}$ Secondly, the king was decisive in declaring war and making peace. ${ }^{75}$ Thirdly, the king could assign offices. ${ }^{76}$ Fourthly, the king functioned as the highest court of appeal. ${ }^{77}$ Finally, the king was able to grant clemency. ${ }^{78}$ If the prince (for example, the King of France) administers sovereignty well, he is a good prince. In other words, how well a prince performs defines the type of government over the principality: it is the performance of the prince, the extent to which he lives up to Botero's ideal that determines whether a particular government is monarchical or tyrannical. Alternatively, in the words of Foisneau, the difference between Bodin and Botero is that they have: '[ . . ] the perspective of an unlimited normative authority in the one case, and as an art of ruling in the other case $[\ldots.]{ }^{79}$ Richelieu boldly interpreted Botero's reason of state as an excuse to violate people's personal lives under the pretext of pursuing France's interests.

Furthermore, under Richelieu, the role of the king—as sovereign—was much more focussed on administering legislation to France, the land given by God to the people of France. The juridical and theological roles of the king merged into one another, and profoundly influenced perceptions of the term sovereignty. ${ }^{80}$ Again, the reason of state and the interests of the prince became two sides of the same coin.

The wars of the sixteenth century - whether called wars of religion, or civil wars-were perceived as a severe threat to the survival of the country. ${ }^{81}$ This 'threat to the very survival of the patrie [during the Wars of Religion] called forth one of the most massive outbursts of patriotic writings of the early modern period ${ }^{82}$ Nevertheless, the content of these writings may well have been the result of much earlier discussions about the organisation of government, and the question of what the latter's core business was supposed to be. The prince should preserve, and provide for, the res publica (commonwealth), or, in French, the bien public. ${ }^{83}$ Between 1547 and 1610 , this subsequently shifted from a focus on the 'bien $d u$ pubic' to the 'bien

\footnotetext{
${ }^{74}$ Bodin (1576), p. 221 '[ . . ] c'est la puissance de donner loy à tous en general, \& à chacun en particulier.'

${ }^{75}$ Ibid., p. 221 '[ . . .] comme decerner la guerre ou traicter la paix, qui est l'un des plus grands poincts de la majesté, d'autant qu'il tire bien souvent après soi la ruine, ou l'asseurance d'un estât.'

${ }^{76}$ Ibid., p. $228^{6}[$ [.. .] d'instituer les principaux officiers [...].'

${ }^{77}$ Ibid., p. 231 '[. . . ] c'est à sçavoir du dernier ressort.'

${ }^{78}$ Ibid., p. 236 [. . .] la puissance d'ottroyer grace aux condamnés par dessus les arrests, \& contre la rigueur des loix, soit pour la vie, soit pour les biens, soit pour l'honneur, soit pour le rappel du ban, il n'est pas en la puissance des Magistrats, pour grands qu'ils soyent, d'en donner un seul poinct, ny de rien alterer des jugements par eux donnés.'

${ }^{79}$ Foisneau (2013), p. 332.

${ }^{80}$ Ibid., p. 333.

${ }^{81}$ Nice (2006).

${ }^{82}$ Ibid.; Ranum (1975), p. 45 quoting here: W.F. Churche 'France'.

${ }^{83}$ Collins (2021), chap. introduction.
} 
de la chose publique', and finally to the 'bien de l'Estat' ${ }^{84}$ With that, officials manoeuvred away from intrusive popular activities and pronounced that France was raised above personal interests. According to Collins, authors often petitioned the king, asking him to act for the good of the patrie as well. ${ }^{85}$ As such ' $[\ldots]$ in a Republic, the patriotic citizen who believes the war to be against the interests of the common good, shows his patriotism precisely by speaking out against it. ${ }^{86}$ In December 1576, Henry III used the expression 'the honour of God, the service of the king, and the good (bien) and peace (repos) of the patrie' in a letter. ${ }^{87}$ When Henry III disbanded several meetings of the états, this was perceived as a violation of the commonwealth.

As from 1594, the word Estat or 'state' began to appear frequently at every level of political communications. Collins mentions that the city of Abbeville took an oath to conserve 'his [Henry IV's] state and crown' ${ }^{88}$ He illustrates that the word Estat competed with the term patrie; the terms could be used interchangeably. The term patrie applied to towns and provinces, but also the Commonwealth of France.$^{89}$ It is important to note that a strong emotional connection seems to be indicated when the term patrie was applied. The term estat, on the other hand, was less emotionally charged. For instance, when the états of Brittany sent an envoy to negotiate with the English Queen for support, their diplomat was pressed to act on behalf of the patrie, meaning Brittany. ${ }^{90}$

According to Marc Greengrass, the term patriot, in particular, was used during periods of war and turmoil during the sixteenth century to monopolise favours. ${ }^{91}$ Patriot illustrated one's passions. ${ }^{92}$ Protecting the patrie from the king was a dangerous act, as can be illustrated by the cases mentioned above of Jacques Clément and François Ravaillac as they believed that the king did not uphold the Catholic faith. ${ }^{93}$ Such excesses may have contributed to a decline in the use of the term patriot in political communications at the highest levels, for example, in political texts of provinces such as Brittany. By the beginning of the seventeenth century, the term patrie was replaced by estat, or 'state' in most forms of communications. ${ }^{94}$ At the local level and in religious texts, however, the term patrie was

\footnotetext{
${ }^{84}$ Ibid., chap. Henry IV.

${ }^{85}$ Ibid., chap. Henry IV.

${ }^{86}$ Ibid., chap. introduction.

${ }^{87}$ Collins, chap. Henry IV: citing Le Roux, Un Régicide au nom de Dieu, 64.

${ }^{88}$ Collins, chap. Henry IV: quotes here Abbéville, 483.

${ }^{89}$ Ibid., chap. Henry IV.

${ }^{90}$ Ibid., chap. Henry IV.

${ }^{91}$ Greengrass (2005).

${ }^{92}$ Ibid., p. 302.

${ }^{93}$ Greengrass (2004).

${ }^{94}$ Collins (2021).
} 
still used..$^{95}$ There is still much more research to be done into the when and where, and the changes in the application, of the local use of the word patrie in Brittany. ${ }^{96}$

\section{References}

Bély L (1998) The peace treaties of Westphalia and the French domestic crisis. Historische Zeitschrift Beihefte, New Series 26:235-252

Bély L (2009) La France au XVIIe siècle: puissance de l'État, contrôle de la société. Presses universitaires de France, Paris

Benedict P (2016) Were the French wars of religion really wars of religion? In: Palaver W, Rudolph H, Regensburger D (eds) The European wars of religion: an interdisciplinary reassessment of sources, interpretations, and myths. Routledge, London, pp 60-86

Bodin J (1576) Les Six Livres de la République. Jacques du Puy, Paris

Bonney R (1981) Cardinal Mazarin and the great nobility during the Fronde. English Hist Rev 96:818-833

Bonney R (1984) La Fronde des officiers: mouvement reformiste ou rebellion corporatiste? XVIIe Siecle 145:323-340

Bonney R (1989a) Was there a Bourbon style of government? In: Cameron K (ed) From Valois to Bourbon: dynasty, state and society in early modern France. University of Exeter, Exeter, pp 161-177

Bonney R (1989b) Mazarin et la Fronde : la question de responsabilité. In: Duchêne R, Ronzeaud P (eds) La Fronde en questions. Publications de l'Université de Provence, Aix-en-Provence, pp 329-338

Bonney R (1991) The king's debts: finance and politics in France 1589-1661. Clarendon Press, Oxford

Bonney R (1992) Louis XIII, Richelieu, and the royal finances. In: Belgin JA, Brockliss L (eds) Richelieu and his age. Oxford University Press, Oxford, pp 99-133

Bonney RJ (1978) The French civil war, 1649-53. Eur Stud Rev 8:71-100. https://doi.org/10.1177/ 026569147800800104

Bonney RJ (1979) The failure of the French revenue farms, 1600-601. Econ Hist Rev 32:11-32. https://doi.org/10.1111/j.1468-0289.1979.tb01811.x

Bulst N (2004) France in the Fifteenth Century. In: von Friedeburg RCF (ed) Murder and monarchy: Regicide in European history, 1300-1800. Palgrave Macmillan, Houndmills, pp $122-135$

Carrier H (1969) Machiavel dans les pamphlets de la Fronde. In: Actes L'Italianisme en France au XVIIle siècle Actes du VIIIle congrès de la Société française de littérature comparée. Turin, pp $39-46$

Chisholm H (ed) (1911) Luynes. Encyclopædia Britannica. Cambridge University Press, p 147

Collins JB (2001) The state in early modern France. Cambridge University Press, Cambridge

\footnotetext{
${ }^{95}$ Ibid. illustrates the use of this vocabulary for the city of Rouan (Normandy); Jason Nice focusses on the ecclesiastical usage of the words, see: Nice (2009).

${ }^{96}$ So far, no-one has taken up the challenge of exploring the Délibérations de la communauté de ville Rennes (see: http://www.archives.rennes.fr/archives-et-inventaires/archives-en-ligne/delibera tions-de-la-communaute-de-ville/) which offers material for an entire dissertation.
} 
Collins JB (2003) Classes, estates and order in early-modern Brittany. Cambridge University Press, Cambridge

Collins JB (2017) Dynastic Instability, the Emergence of the French Monarchical Commonwealth, and the Coming of the Rhetoric of 'L'état', 1360s to 1650s. In: von Friedeburg RCF, Morrill JS (eds) Monarchy transformed: princes and their elites in early modern Western Europe. Cambridge University Press, Cambridge, pp 87-126

Collins JB (2021) The French Monarchical Commonwealth, 1356-1561. Cambridge University Press, Cambridge

Foisneau L (2013) Sovereignty and reason of state: Bodin, Botero, Richelieu and Hobbes. In: Lloyd HA (ed) The reception of Bodin. Brill, Leiden/Boston, pp 323-342

Greengrass M (2004) Regicide, Martyrs and Monarchical authority. In: von Friedeburg RCF (ed) Murder and monarchy: regicide in European history. Palgrave Macmillan UK, Houndmills, pp 1300-1800

Greengrass M (2005) Passions and the Patria: Michel de L'Hospital and the reformation of the French polity in the wars of religion. In: von Friedeburg RCF (ed) 'Patria' und 'Patrioten' vor dem Patriotismus: Pflichten, Rechte, Glauben und die Rekonfigurierung europäischer Gemeinwesen im 17. Jahrhundert. Harrassowitz in Kommission, Wiesbaden, pp 287-308

Jouhaud C (1983) Écriture et action au XVIIe siècle : sur un corpus de mazarinades. Annales Histoire, Sciences Sociales 38:42-64. https://doi.org/10.3406/ahess.1983.411037

Jouhaud C (1985) Mazarinades: la Fronde des mots. Aubier, Paris

Kettering S (1986) Patronage and politics during the Fronde. French Hist Stud 14:409-441. https:// doi.org/10.2307/286384

Kossmann EH (2000) Political thought in the Dutch Republic: three studies. Koninklijke Nederlandse Akademie van Wetenschappen, Amsterdam

Medick H, Marschke B (2013) Experiencing the thirty years war: a brief history with documents. St. Martins, Bedford, Boston

Moote AL (1971) The Revolt of the Judges: the Parlement of Paris and the Fronde, 1643-1652. Princeton University Press, Princeton

Mousnier R, Spencer J (1973) The assassination of Henry IV. The tyrannicide problem and the consolidation of the French absolute monarchy in the early seventeenth century. Faber and Faber, London

Nice J (2009) Sacred history and national identity. Comparisons between Early modern wales and Brittany. Pickering \& Chatto, London

Nice JA (2006) 'The peculiar place of god': early modern representations of England and France. Engl Hist Rev CXXI:1002-1018. https://doi.org/10.1093/ehr/cel210

Ranum O (1975) National consciousness, history and political culture in Early-Modern Europe. The Johns Hopkins University Press, Baltimore

Schalk E (1986) Clientage, elites, and absolutism in seventeenth-century France. French Hist Stud 14:442-446. https://doi.org/10.2307/286385

Sonnino P (1998) Prelude to the Fronde. The French delegation at the peace of Westphalia. Historische Zeitschrift Beihefte New Series 26:217-233

van der Linden D (2016) Experiencing exile: Huguenot refugees in the Dutch Republic, 1680-1700. Routledge, Abingdon, Oxon

Viroli M (2005) From politics to reason of state: the acquisition and transformation of the language of politics 1250-1600. Cambridge University Press, Cambridge 
Open Access This chapter is licensed under the terms of the Creative Commons Attribution 4.0 International License (http://creativecommons.org/licenses/by/4.0/), which permits use, sharing, adaptation, distribution and reproduction in any medium or format, as long as you give appropriate credit to the original author(s) and the source, provide a link to the Creative Commons license and indicate if changes were made.

The images or other third party material in this chapter are included in the chapter's Creative Commons license, unless indicated otherwise in a credit line to the material. If material is not included in the chapter's Creative Commons license and your intended use is not permitted by statutory regulation or exceeds the permitted use, you will need to obtain permission directly from the copyright holder. 